\title{
The Role of Ego in Margayya's Fall in the Financial Expert -A Psychological Approach
}

\author{
Mr. P. Jose \\ Research Scholar \\ Kovaipudur, Coimbatore, Tamil Nadu, India \\ josejonu@gmail.com
}

\section{Abstract}

Ego is one of the most important elements in human personality and although everyone has ego, people manage their ego differently. Some people take it very seriously and act in a way to retaliate, if their ego is hurt while others think and balance their ego before it builds aggression which would bring their own downfall. Since people are driven by their egocentric mindset, any disgrace, disappointment or failure would hurt their ego which would force them to build aggression, reduce rational thinking and lead them to engage in unethical and illegal acts. When Margayya's ego was hurt by the secretary of the bank when he insulted him and almost ended his finance career, he wanted to accumulate more wealth. He didn't worry about the ways and means but focused on the destination and he was guided by his ego that led him to mistreat and disrespect people throughout the novel. His obsession with money and prestige forced him to act rudely that ended his career as one of the best financial wizards. When people are led by their ego, it would lead them to their own downfall and destruction as they would be guided by lack of self-control and distrust on others. His obsession with money led him to show off his superiority in order to defeat the cooperative bank secretary and earn respect in the society. This paper brings out the Psychological influence of ego in Margayya's character in the novel, The Financial Expert. 
Keywords - The Financial Expert, R.K.Narayan, Margayya, Ego, Role of Money.

In the Beginning

Margayya started his life as a simple man who helped the villagers in that region to get unlimited loan from the cooperative bank and helped them with the forms. For people in the villages around them, Margayya was the only solution for their financial troubles. His name margayya was a given name as his real name was Krishnan. Marg means way and ayya means an honourable word which is used to show respect to the person addressed. Margayya was showing the way for the financial struggles of villagers, and he was a respectful person in the eyes of the villagers. Although the bank didn't like middlemen in their business, Margayya was happy about beating that principle. As the novel brings out, "If the purpose of the co-operative movement was the promotion of thrift and the elimination of middlemen, those two were just the objects that were defeated under the banyan tree". (The Financial Expert 8). Margayya never thought of running behind money and become an ultra-rich man until he was insulted by the bank's secretary, which hurt his ego very much. The fact that he was rude because of the respect he gathered from the villagers who thought he was a man in need when they needed any help suggests that he thought himself as one of the most important persons in their lives. This is brought by the novelist through the voice of a villager: "Oh, they are all very bad, unhelpful people, sir; that's why I never like to go there, but come to you first. Why do we come to you, sir, of all persons in this big city? It's because you know our joys and sorrows and our troubles, our difficulties and --" (The Financial Expert 26). In a traditional Indian village, those who help others would become the village heads and Margayya in the novel feels no less than that. 
The problem

Arul Doss the head peon of the cooperative bank was sent by the bank's secretary to warn Margayya to quit his business under the banyan tree. When he came to Margayya and told him that the Secretary wanted him to come and meet him, Margayya replied arrogantly, "Tell your Secretary that if he is a Secretary, I am really the proprietor of a bank, and that he can come here and meet me if he has any business---" (The Financial Expert 24). He even told Arul Doss that if he wanted a job, he could come to him. Margayya always wanted to uphold his status quo among the villagers who considered him as a demi-god who could solve all their financial problems. Arul Doss, knowing how adamant and indifferent Margayya was, went back and reported it to the Secretary who came out to meet Margayya.

When Arul Doss told Margayya that he should respect the secretary, otherwise he would throw him in prison, he didn't like the threat and domination in the head peon's voice. He replied back angrily“Stop your nonsense, you earth-worm! Things have come to this, have they, when every earth-worm pretends that it is a cobra and tries to sway its hood....I will nip off your head as well as your tail, if you start any of your tricks with me. Take care. Get out of my way" (The Financial Expert 28). Margayya was both scared and powerful at once because he knew that the secretary is capable of throwing him in prison while at the same time, he is good at dealing people like Arul Doss. However, he was worried that he talked too much but his ego wouldn't let him apologize but forced him to pose himself as powerful person. When the Secretary finally used his power and threatened Margayya, he felt ashamed of not having any money, power or privilege and returned home with a hurt ego. The Change

Margayya took everything that happened in front of the cooperative bank to his heart, and he was not able to digest the fact that both Arul Doss and the secretary insulted him because of his social status. It was this event that acted as the driving force behind 
Margayya's obsession with money, power and social status. It's brought out by Nazar Singh Sidhu, "Margayya at once connects this lack of power and status with power of money. He can be as big, as respectable and as powerful as the Secretary if he has money. This consciousness of power through money becomes his obsession. Almost a morbid state of mind develops. He begins to see the world in terms of his lack and henceforth directs all his efforts towards filling up this void. Arul Doss and the Secretary serve as the symbolic reminder of this void." (Sidhu 71). Although Margayya was an ordinary man leading an ordinary life, he started turning into a demon who chased money. He started to believe that money is everything and he could buy everything with money, including respect and power. The thought of lack of money blinded his reason and his mind was clouded with the thoughts of living a life like the secretary that would make him rich, affluent and powerful.

Human ego is one of the most important weapons and when it is used positively, it would help people make their lives but if it is used negatively with aggression, indifference and retaliation, it would mar their lives. When people are humiliated, it would hurt their feelings, emotions and self-esteem but if they do not take it in a right sense, they would be forced to engage in irrational acts as they would be blinded by their inability to think. It would force them to overcompensate for what they are humiliated. As Harish Raizada suggests "Margayya is so much obsessed by the power and importance of money in human life that every little humiliation he faces, reminds him of his own lack of money." (Raizada 104). Margayya knows that he shouldn't be under the banyan tree diverting and corrupting the customers of the bank in order to promote his business, besides, he was also using the bank's forms. However, he is forced to believe that it's his right to do business in anyway he wants which led him to his doom at the end. 
The Process

Margayya came home disgraced and ashamed and when his wife told him that he shouldn't have fought with the secretary and Arul Doss because they were earning more money, he felt that even his wife thinks that poor people shouldn't show their self-respect. It hurt his ego further and he felt cornered everywhere. Although he accepts that the secretary has every right to threaten, he was not able to accept the fact that he humiliated him in front of everyone. This is mentioned in the novel, "He has every right because he has more money, authority, dress, looks-above all, more money. It is money which gives people all this. Money alone is important in this world. Everything else will come to us naturally if we have money in our purse." (Financial Expert 32). However, he also tells his wife that he would become richer than the secretary and the secretary would call him mister and stand-up when he enters. He wanted everyone to respect him including his brother living next door with whom he was not in good terms.

Margayya was a religious man who was guided by his religious beliefs thus, when he came into contact with the temple priest, he asks him what he could do to become a rich man. The temple priest wanted to see his horoscope to provide him solutions and remedies that would help him amass wealth and power. P. S. Sundaram brings out his anguish and search for spiritual support, "Convinced that money is the only thing that matters, Margayya consults a temple priest regarding his future and the quickest way of making a fortune. His stars, he is told, are propitious: he must worship the goddess of wealth for forty days, with the ash of a red lotus and ghee made out of butter from milk drawn from a smoke-coloured cow." (Sundaram 60). He searched all his old possessions in order to find his horoscope which would help him pursue his purpose and achieve his greatness. Margayya considered the specifics mentioned by the temple priest was intriguing and unusual, but he was ready to go to any extent to achieve his dream. In a typical Indian household, god comes first and it's 
goddess of wealth, Lakshmi who rules the households.Margayya was ready to go to any extent to fill himself with the presence of goddess Lakshmi.

Margayya was looking to become rich in a short time because he was not led by his reason but by his ego that was hurt. He was desperate which led him to do everything that the priest asked him to do although most things were new to himself. P. K. Singh brings out this by stating "The novel shows us the people's existing ambition for earning more and more money in a short time. Narayan wants to say that a man without corresponding ability cannot succeed in earning desired wealth and power. He also draws our attention towards the evils arising out of the wealth." (Singh 35). When people are guided by their ego, they would engage in actions that would bring disgrace to themselves and their families and Margayya just started heading towards his downfall as he was blinded by his ego and pride.

The Progress

His aim was to satisfy his ego by making more money at any cost and feel the satisfaction of retaliation against the secretary and Arul Doss who he felt were the only people who have lined-up against him although they were doing their duties. Margayya started his own financial business by promising people with exorbitant amount of interest at 20 percentage. Harish Raizada comments: "Though already very rich, Margayya is still not satisfied with his position. His calculating brain plans a new scheme of starting a bank of his own and making the most of the inflated currency of war time. He draws clients by paying them the exorbitant interest of twenty percent." (Raizada 102). People were lured by this attractive interest and started depositing their money with Margayya rather than with the cooperative bank. He used all his charm to amass large amount of money and deposits from villages all around poured in. He was running his own small empire and villagers spread the news orally and he didn't need any advertising. People were happy about gaining more interest for their deposits without worrying about the safety of their money in one man's 
hand.P.K.Singh brings out this transformation as "Margayya, a middle-aged moneylender, carries his business under the shade of banyan tree in front of the Co-operative Society. His chief ambition is to soar high in status by earning huge wealth. He is, therefore, always in look out to find a 'get-rich' device. He later on succeeds in spinning a big money. Margayya exploits the innocent villagers and earns money." (Singh 32). The fact that Margayya had lots of clients and acquaintances while he was working under the banyan tree made it possible for him to convert this connection and make them his customers.

His reputation grew and his wealth too. He also used lots of tricks on the poor villagers that those who were not able to return the money on time started losing their properties and belonging because he was very good at charging compound interest from the villagers that helped him build his wealth. As William Walsh points out"People under stress came to Margayya because he was so accommodating and unfussy about formalities. He advanced cash easily and promptly. He charged interest in so subtle a way and compounded it so deftly that anyone who signed one of his bonds was more or less finished." (Walsh 84). He knew that he could survive only if he gives more interest for the deposit while at the same time charging more interest for the loans. The fact that his wealth was slowly drained by his son's lavish life and irresponsibility suggests that Margayya was heading towards his own doomsday.

The Fall

The problem started when he didn't know what to do with the money he was accumulating because he was not a businessman but an ordinary man who was blinded by his ego which ultimately led him to his fall. He enjoys the thrill of seeing the money that flows from everyone. P. S. Sundaram brings out this state of mind of Margayya"When he sees money increasing and multiplying itself without any effort on his part, he is simply fascinated. He enjoys the incidental power which money brings, whether in his son's school 
or among the people of Malgudi. But he is not primarily interested in power. He has no idea what to do with the millions that come his way -he opens no business or enterprise, builds no monopoly or empire." (Sundaram 63). He seems to be happy with the money flow without worrying about investing them or use them to build his business or invest them elsewhere such as in assets. Margayya enjoyed the status and power his wealth was earning for him, and he felt that his ego was being satisfied.

This mindset was coupled with his aggressive attitude led him to treat his customers disrespectfully. When a villager came to take his deed back after his repayment Margayya treats him with disrespect and rudeness which is portrayed in the novel, "And yet you have not the grace to trust me with your title. Do you think I am going to make a broth of it and drink it?" (The Financial Expert 151). He was not only rude but indifferent with his depositors as he continued to show his superiority over them which comes from his belief that he was rich thus, commands respect. Although he used to behave rudely and aggressively right from the time, he was doing business under the banyan tree, he became very rude after becoming rich that he thought he was a demi-god.

The End

Margayya started believing that only money could redeem him from all his miseries thus, he started living amidst money and his account books without getting enough sleep or without spending any quality time with his family. When people run after money, they would be blinded from the people they love, duties and responsibilities they have and the social norms they have to follow. Margayya identifies himself with money, prestige, and social status which Lakshmi Holmstrom brings out as“Margayya's attitude to money is what makes him what he is. Money gives him both a meaning in life and a station in the universe. His habit of metaphysical speculation arises only from the mystic feeling that money engendered and from no other experience." (Holmstrom 53). When people run behind money and 
motivated by their ego, they would go to any extent and would think that they would be happy if their ego is satisfied and that they would compensate for what they lack.

Margayya's end became imminent when he was not satisfied with what he had but when he was still running after money without doing anything meaningfully. His ego was running wild and his wife was worried about his health and his present state of mind. He was on his own most of the time and he pretended to be normal by using his aggressive attitude as always with his wife. When his wife tells him that he would spoil his health, he just ignores her. Although ordinary readers would sympathize with him for his traumatic change, Margayya chose his life on his own which suggests that he deserves it. Jayant K. Biswal brings out his oscillation between two realities, "In Margayya, dream and reality operate together in a network of strange and unpredictable relationships. Margayya earns the sympathy of the readers because of his basic simplicity and humiliation he faces because of his socio-economic condition.”(Biswal 85).

Margayya lost everything when the depositors wanted their money back. His son contributed to his problem by spending most of his money and he himself was not making any progress in terms of his business. He just felt proud of his achievement, and he was happy that he amassed lots of wealth without realising that it was not his money. When news spread that Margayya was not in a position to repay the deposit money, people crowded his house and he announced insolvency and requested for police protection. However, at the end of the novel which comes after four months, he ended up where he was insulted once, facing the same people again.

Conclusion

People are the products of their environment, and their values, beliefs, attitudes and worldview would be greatly influenced by their environmental factors. This would mean that their identity would be built from their environment and anything that threatens their identity 
would also hurt their ego which is the source of their self-esteem, self-respect and selfconfidence. When Margayya's ego was hurt by the secretary of the cooperative bank he felt that he was being cornered by the whole world. So, he waged a war against the whole world by treating people disrespectfully, deceiving people in order to earn more money, not taking care of his family, spoiling his son with material resources etc. He chose a path that led him to his downfall and at the end of the novel, he went back to where he started, under the banyan tree. He was living a ghostly life which alienated him from his surroundings and loved ones. When people are overwhelmed by their ego, they would only see the destination and not the path they choose and, in the process, they would hurt many people which they wouldn't normally do. Margayya became the victim of his own pride, obsession, aggressiveness and indifference that were all part of his ego. 


\section{Works Cited}

Biswal, Jayant K. A Critical Study of the Novels of R. K. Narayan: The Malgudi Comedy. New Delhi: Nirmal Publishers and Distributors, 1987.

Holmstrom, Lakshmi. The Novels of R. K. Narayan. Calcutta: Writers Workshop Publication, 1973.

Narayan, R.K. The Financial Expert. Chennai: Indian Thought Publications, 2007.

Raizada, Harish. R. K. Narayan: A Critical Study of His Works. New Delhi: Young Asia Publications, 1969.

Sidhu, Nazar Singh. Human Struggle in the Novels of R.K. Narayan. New Delhi: Bahri Publications, 1992.

Singh, P.K. The Novels of R. K. Narayan: A Critical Evaluation. New Delhi: Atlantic Publishers and Distributors, 2001.

Sundaram, P.S. R. K. Narayan as a Novelist. Delhi: B. R. Publishing Corporation, 1988.

Walsh, William. R.K. Narayan: A Critical Appreciation. New Delhi: Allied Publishers Private Limited, 1983. 